\title{
Determinants of Internal Audit Effectiveness in Decentralized Local Government Administrative Systems
}

\author{
George Tackie ${ }^{1}$, Edward Marfo-Yiadom ${ }^{1} \&$ Sampson Oduro Achina ${ }^{2}$ \\ ${ }^{1}$ School of Business, University of Cape Coast, Cape Coast, Ghana \\ ${ }^{2}$ College of Distance Education, University of Cape Coast, Cape Coast, Ghana \\ Correspondence: George Tackie, School of Business, University of Cape Coast, Cape Coast, Ghana. E-mail: \\ gtackie@ucc.edu.gh
}

Received: April 27, 2016

Accepted: September 29, $2016 \quad$ Online Published: October 27, 2016

doi:10.5539/ijbm.v11n11p184

URL: http://dx.doi.org/10.5539/ijbm.v11n11p184

\begin{abstract}
This paper examines the determinants of internal audit effectiveness in decentralized local government administrative systems of Ghana. Ghana's local government system is structured into metropolitan, municipal, and district assemblies (MMDAs). For the purpose of the study, we focused on the Ashanti region of Ghana which has the highest number of MMDAs. The motivation for the study is derived from the increased interest in the internal audits of local government units. Using a descriptive survey, the data gathered, through the use of questionnaire, revealed that majority of the internal audit staff of MMDAs in the Ashanti Region of Ghana possess the requisite professional proficiency. Contrary to the perception that audit quality in the public sector is usually compromised, the study revealed that there exists high quality of audit work due to compliance with the international standards on auditing and local audit legislations. Professional proficiency, organizational independence, and career advancement were found to have statistically significant positive relationship with internal audit effectiveness, whiles top management support was found to have no effect on internal audit effectiveness.
\end{abstract}

Keywords: district assemblies, internal audit effectiveness, local government

\section{Introduction}

Internal auditing (IA) is a profession and an activity related to advising organisations regarding how to better achieve their objectives through managing risk (Ali, Gloeck, Ali, Ahmi, \& Sahdan, 2007) and improving their internal control systems (Millichamp, 2002). It involves the utilisation of a systematic methodology for hianalysing business processes or organisational challenges and recommending solutions (Asare, 2008). The focus of IA is to assist members of an organization in the effective discharge of their responsibilities. This is achieved through the provision of relevant audit appraisals and recommendations concerning the activities reviewed (Ali, Gloeck, Ali, Ahmi, \& Sahdan, 2007).

In 1978, the Institute of Internal Auditors (IIA) defined internal auditing as an independent appraisal activity established within an organisation as a service to the organisation. It is a control, which functions by examining and evaluating the adequacy and effectiveness of other controls (IIA, 1978). Historically, internal auditing, as Asare (2008) posits, has been perceived as being merely the proper maintenance of accounting and underlying records, the safe guarding of assets and the compliance with policies and procedures. With changing times, the concept of internal auditing has undergone significant changes with regard to its definition, scope of coverage and approach. Asare (2008) asserts that, in some organisations, the scope of modern internal auditing has been broadened from financial issues to include value for money, evaluation of risk, managerial effectiveness and governance processes. In 2002, the Institute of Internal Auditors (IIA), revised its definition of the internal audit function as "an independent, objective, assurance and consulting activities designed to add value and improve an organisation's operations. This helps an organisation accomplish its objectives by bringing systematic, disciplined approach to evaluate and improve the effectiveness of risk management control, and governance processes.

With the increased emphasis on accountability, transparency and improvement in public sector performance especially in the developing countries where the various stakeholders including civil society and the media are 
becoming more interested in how public funds are allocated and expended, it is imperative that governments are seen to have a sense of responsibility coupled with an efficient and effective financial control mechanism. Asare (2008) was right when he noted that public sector auditing, particularly internal auditing is useful in managing public expenditure, ensuring financial accountability, and strengthening governance systems of public institutions.

Under Ghana's Financial Administration Decree, 1979, SMCD 221, the Auditor-General has the legal mandate to carry out internal audit activity in the Metropolitan, Municipal and District Assemblies (MMDAs) of Ghana. Staff at the internal audit units of these MMDAs mainly concentrate on pre-auditing of payment vouchers. Overtime, no improvements were recorded in the internal control system as weaknesses were being repeated on an annual basis. According to Ghartey (2003), there was also the risk of conflict of interest with officers having to perform possibly the roles of both accounting as well as internal auditing in the same or related departments. As noted by Abbey (2010), the threat to effectiveness and integrity became apparent in a series of scandals in the mid-1980s involving officers of the Audit Service, acting as both internal and external auditors at the Ghana Education Service that caused a huge financial loss to the state. A review of this function revealed limitations on the scope of the audit function and unsatisfactory reporting relationship. This resulted in the establishment of a central Internal Audit Agency (IAA) to enhance efficiency, accountability and transparency in the management of resources in the public sector (Nomo, 2009).

Many studies on the effectiveness of IA in Ghana and elsewhere have been conducted (see for examples, Mihret \& Yismaw, 2007; Asare, 2008; Ernst \& Young, 2008; Nomo, 2009; Abbey, 2010; PricewaterhouseCoopers, 2010; Bota-Avram \& Palfi, 2009); Arena \& Azzone, 2009); Cohen \& Sayag, 2010; Karagiorgos, Drogalas \& Giovanis, 2011). However, to the best of our knowledge, no research has focused on the internal audit effectiveness of decentralized local government administrative systems in a developing regional context. Using the Internal Audit Agency Act of Ghana as the lens, this study focuses on assessing the internal audit effectiveness of MMDAs in the Ashanti region which has the highest number of 30 MMDAs in Ghana.

The next section of the paper is devoted to a brief review of theoretical and empirical evidence as well as the development of the conceptual framework related to the internal audit function, and internal audit effectiveness. This is followed by an exposition of the research methodology employed for this study, and the discussion of the results of the study. The paper concludes with some recommendations.

\section{Review of Theoretical and Empirical Evidence}

In this section, we examine the definitions of the main variables used in the study and provide reviews of some theories of internal auditing and local governance decentralisation. This section also reviews empirical literature on effectiveness of internal audit and its determinants. Also, the role of internal auditing in governance, risk management and control are examined. The section concludes with a conceptual framework which we crafted from the theories and literature reviewed.

\subsection{The Concept of Internal Auditing}

Asare (2009) asserts that the modern concept of internal auditing can be identified as involving the evaluation and improvement of risk management, control and governance processes. Risk management, control and governance encompass the policy and procedures established to ensure the achievement of objectives and include the appropriate assessment of risk, the reliability of internal and external reporting and accountability processes, compliance with applicable laws and regulations and compliance with the behavioural and ethical standards set for an organization and its employees. Risk management relates to the activities and actions taken to ensure that an organization is conscious of the risks it faces, makes informed decisions in managing these risks, and identifies and harnesses potential opportunities. Control includes all the policies and procedures put in place by management; aimed at promoting accountability of resources whiles governance relates to the means by which goals are established and accomplished by ensuring creditability, equitable provision of services, assurance of appropriate behaviour and reduction in the risk of corruption (IIA, 2006).

\subsection{Theories of Internal Auditing}

In this paper, we draw on two theories as bedrocks for our investigation. These are the profession theory and the institutional theory. Professions can be interpreted in ambivalent ways, from the rise of professions as knowledge triumphant to a malfeasance of a monopoly of knowledge (Abbott, 1988). With the growing rate of information and knowledge, professions occupy a key position in society. In this sense, the internal auditing profession is key to ensuring that organizations remain sound; emphasizing on objectivity, confidentiality and competency. Winters (2009) also argues that, individual internal auditors can only achieve their full potential if the profession as such is strengthened. Important steps to advocate the profession include: Complying with standards, 
communicating to senior management and the audit committee about internal auditing role and value in providing assurance, developing supportive mentoring with colleagues and clients.

Institutional theory explains how organizational structures and practices are shaped through changes induced by normative pressures, including both external and internal sources such as laws and regulations, or by the professions (Zucker, 1987; Mihret et al., 2010). Several previous studies on internal audit have drawn on the institutional theory (Al-Twaijry et al., 2003; Arena \& Azzone, 2006; Arena \& Azzone, 2007; Mihret et al., 2010). Empirical works cited from these studies tend to suggest that the institutional theory is a valid theory for internal audit effectiveness which has been employed in both developed and developing regions.

\subsection{Internal Audit Effectiveness}

The Institute of Internal Auditors (IIA) (2010) defines internal audit (IA) effectiveness as "the degree (including quality) to which established objectives are achieved." It is the extent to which an internal audit office meets its purposes (Mihret \& Yismaw, 2007), and can refer to ability of auditors, internal or external, to achieve established objectives within an organisation (Mizrahi \& Ness-Weisman, 2007; Arena \& Azzone, 2009; Dittenhofer, 2001; Karapetrovic \& Willborn, 2000). The objectives of an internal audit unit for every organisation depend on the goals set out by the management of such an organisation (Pungas, 2003). Even though the degree of internal audit effectiveness tends to vary within organisational levels as well as country (Al-Twaijry et al., 2003), the management of organisations should have a clear objective for internal auditors to achieve, given the available resources and other means that might aid the achievement of such objectives. It is argued that the effectiveness of an internal audit unit depends on the expectations of relevant stakeholders even though systematic and generally valid measures can be used to gauge IA effectiveness (Dittenhofer, 2001).

\subsection{Determinants of Internal Audit Effectiveness}

We adapted the determinants of effective internal auditing as used by Cohen and Sayag (2010). The first three determinants (professional proficiency of the auditors; the quality of auditing work; and the organisational independence of auditing departments) represent instances where the auditor's interests reflect those of the profession, rather than the employing organisation. The last two determinants (career advancement; and top management support) represent instances where the interest of the employing organisation takes precedence over that of the internal auditor's profession.

Professional proficiency is the expertise, specialized knowledge and abilities in a field which one is practising professionally. Appropriate staffing of an internal audit department (Al-Twaijry, Brierley, \& Gwillian, 2003) and good management of that staff are keys to the effective operation of an internal audit department. Staff of an IA unit should have the requisite education, training and experience to conduct the full range of audits required by its mandate. Quality of audit work is the degree or extent of excellence in the audit work which is normally achieved when the audit work in performed according to IA standards. Organisational independence is the state, condition, quality or process of being independent through organisational placement and reporting lines of the IA department. Bou-Raad (2000) argues that the strength of an IA department must be assessed with respect to the level of independence it enjoys from management and from operating responsibilities.

Career advancement is an individual's journey through learning, work and other aspects of professional life. It is evident through one's progress in one's job, promotion in rank or improvement in status. Goodwin (2001) posits that, internationally, the practice of staffing the IA department with career auditors is becoming less common, with more organisations using the function as a training ground for future management personnel. This practice is designed to help the organisation train well-rounded senior managers. The last determinant, top management support, refers to high level managers in an organisation giving active approval, encouragement and assistance to employees (Fernandez \& Rainey, 2006).

\subsection{Sequential Theory of Decentralization}

In this study, we draw on the sequential theory of decentralization which follows a set of state reforms proposed by Falleti (2004). Falleti (2004) classifies decentralization policies as belonging to one of three categories administrative, fiscal, and political - depending on the type of authority devolved. Administrative decentralization comprises the set of policies that transfer the administration and delivery of social services such as education, health, social welfare, or housing to sub national governments. Fiscal decentralization refers to the set of policies designed to increase the revenues or fiscal autonomy of sub national governments. An increase of transfers from the central government, the creation of new sub national taxes, and the delegation of tax authority are all examples of fiscal decentralization. Political decentralization is the set of constitutional amendments and electoral reforms designed to open new (or activate existing but dormant or ineffective) spaces for the representation of sub national 
politics. Political decentralisation policies are also designed to devolve electoral capacities to subnational actors. Ghana's decentralized system of governance follows the sequential theory of decentralization. Administratively, the local authorities have the mandate to take charge of education, health care and housing at the local level. In terms of fiscal decentralization, the MMDAs are required to collect some form of revenues in their respective districts. Politically, the district chief executives represents the president of the republic in matters of national interests at the district level.

\subsection{Conceptual Framework for the Study}

In order to vividly represent the phenomenon under investigation, we developed a conceptual framework to assess IA effectiveness. We used the definition of IA and adapted Cohen and Sayag (2010)'s determinants of IA effectiveness. As depicted in Figure 1, we believe that given that an IA unit has the requisite ingredients to perform its role effectively, the overall outcome of IA effectiveness will be value addition to the organisation.

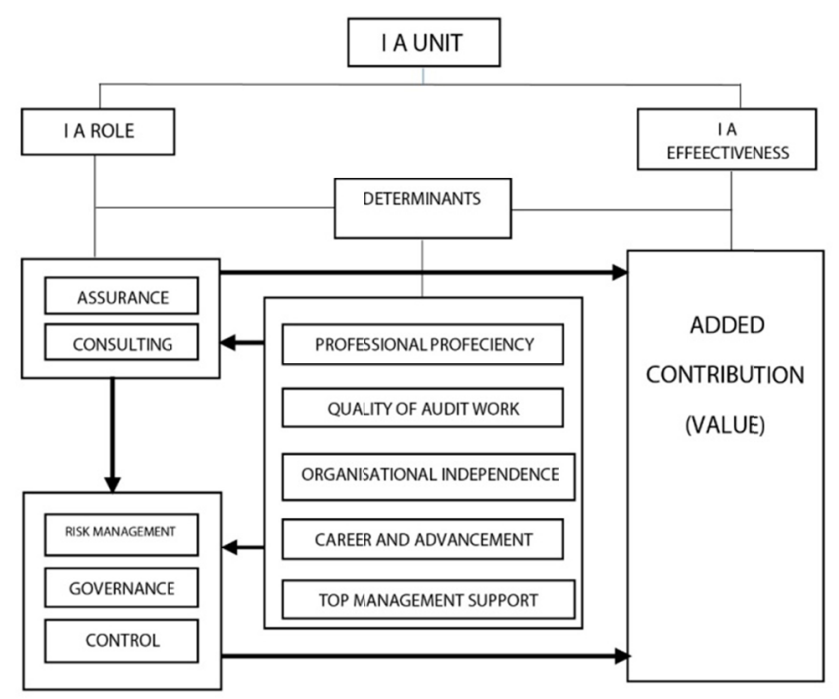

Figure 1. Conceptual framework for the study

Source: Authors' construct, 2014

\subsubsection{Hypothesised Relationships}

Based on the theoretical and conceptual framework of the study, we formulated the following hypotheses:

$\mathrm{H}_{1}$ : The professional proficiency of internal auditors has no effect on IA effectiveness in the MMDAs in the Ashanti Region.

$\mathrm{H}_{2}$ : The quality of audit work of internal auditors has no effect on IA effectiveness in the MMDAs in the Ashanti Region.

$\mathrm{H}_{3}$ : The organizational independence of internal auditors has no effect on IA effectiveness in the MMDAs in the Ashanti Region.

$\mathrm{H}_{4}$ : Career advancement opportunities for internal auditors have no effect on IA effectiveness in the MMDAs in the Ashanti Region.

$\mathrm{H}_{5}$ : Support from top management has no effect on IA effectiveness in the MMDAs in the Ashanti Region.

\section{Research Methodology}

We employed a casual survey research design (Zikmund, 1997) to assess internal audit effectiveness in MMDAs in the Ashanti Region. Our intention is to describe the findings of the study in the context of the developed hypotheses through causal analysis to determine the effect of one variable on the other. Using the Ashanti Region, which is the largest decentralized governmental geographical region in Ghana, primary data through self-administered questionnaire was collected from all the MMDAs in the region. The Ashanti Region also has the highest population and the highest number of MMDAs in Ghana. All internal auditors in the MMDAs in the 
Ashanti region were engaged in the study. Each MMDA has four internal auditors, totalling 120 in number, for the entire region.

The questionnaire was structured to elicit information based on the specific research objectives and the testing of hypotheses. The questionnaire was made up of three parts and made up of closed-ended items, (where respondents were asked to indicate their degree of agreement and disagreement on a five-point Likert scale) and open-ended questions. The instrument was pre-tested in some MMDAs in the Brong Ahafo Region of Ghana. This region was selected because it is fairly large and shares similar characteristics as those of the Ashanti Region. The pre-test was conducted in 10 internal audit units. The purpose was to test for the significance of the items in the questionnaires. It was also to determine the reliability of the rating scales used for the study. The establishment of reliability was accomplished by measuring the internal consistency of the instrument using a reliability coefficient, obtained by means of Cronbach's alpha. A reliability coefficient of .845 was obtained. A scale is considered reliable when Cronbach's Alpha co-efficient is .70 and preferably higher (Pallant, 2005). Even though this reliability is sufficient, few items which were found to be misleading were modified for clarity and accuracy, and others were deleted to standardize the instrument.

The IBM SPSS Statistic (SPSS 17.0 version) was used for processing the data gathered for the study. Data preparation was undertaken in two stages. First, the raw data collected through the questionnaire were edited, coded and converted into the actual variables of interest. Secondly, the variables were checked for other anomalies based on the assumptions made in regression. Prior to major analyses, data were examined using SPSS 17.0 for data entry accuracy, missing values and violation of regression assumptions of normality; linearity, multicollinearity and outliers. Residuals were screened for normality through expected normal probability plots, skewness and kurtosis. The Cronbach's coefficient alpha $(\alpha)$ was used to determine the mean reliability coefficient for the dimensions of social and personality factors. The value of Cronbach's alpha range from 0 to 1 and the closer the value of $\alpha$ to 1 the better the reliability.

\subsection{Model Specification}

In order to address the objectives and test the research hypotheses, we carried out a regression analysis using the following specified model:

$$
I A E=\beta_{0}+\beta_{1} P P+\beta_{2} Q A W+\beta_{3} O I+\beta_{4} C A+\beta_{5} T M S+\varepsilon
$$

Where;

$I A E=$ internal audit effectiveness

$P P=$ professional proficiency

$Q A W=$ quality of audit work

$O I=$ organizational independence

$C A=$ career advancement

$T M S=$ top management support

Using Cronbach's (1951) alpha or the split half reliability measures, the data was tested for goodness of fit. The hypotheses testing was also undertaken to determine whether the hypotheses are substantiated. As a preliminary step, once all the data were coded and entered into the system and verified for any visual errors, the following were obtained using SPSS 17.0 for Windows software: (1) Independent and dependent variables; (2) frequency distribution for the variables; (3) the mean, standard deviation, range and variance on the dependent and independent variables; and (4) a correlation matrix of the variables. These statistics helped to get a feel of the data and indicated that the responses range satisfactorily over the scale. The spread of responses was an indication of the variability and lack of bias. Finally, correlation analysis and regression analysis were performed to test the strength of relationships between variables.

\section{Results and Discussion}

In terms of the relationships between the variables, correlation analysis was applied first to determine the interrelationships among the research variables and to examine the possibility of multi-collinearity. Regression analysis was used to test the other hypotheses. In performing the regression analysis, four assumptions were tested. Also, a regression equation was built to test the hypotheses and in order to assess whether a particular hypothesis is supported or not, the sign of the beta coefficient $(\beta)$ was taken into account. An alpha of 0.01 and 0.05 were used for all tests of significance. 


\subsection{Internal Audit Proficiency}

In relation to the level of the IA proficiency, correlation and regression results were analysed to test the influence of IA proficiency on the effectiveness of the IA departments in the MMDAs. The test results as depicted in Table 1 was analysed into means and standard deviation and ranked in decreasing order for each of the construct measuring the level of IA proficiency. A mean scale of $1-5$ was used, with $1-3$ indicating high level of IA proficiency and $4-5$ indicates low level of IA proficiency. The positive results show that the respondents regard IA proficiency as important. The respondents agreed that the IA units possess the appropriate professional skills, qualification and experience having recorded an average high level of IA proficiency $(M=1.629)$, with a standard deviation of .7415 indicating that the average response is not dispersed from the entire responses collected from the respondents.

Table 1. IA proficiency

\begin{tabular}{ll}
\hline & $M(S D)$ \\
\hline IA unit possess the appropriate professional skills, qualification and experience & $1.629(.7415)$ \\
IA unit has the right mix and competencies in specialist areas such as IT and treasury & $2.407(.9306)$ \\
IA team has an appropriate programme of continuing education & $1.851(.9073)$ \\
Members of the team participate in professional development training programmes. \\
Overall Average
\end{tabular}

Source: Field data, 2014.

Similar results were recorded for audit team members' participation in professional development training programmes and IA team having an appropriate programme of continuing education, with an average response of 1.851. The standard deviations were all below one percent implying the data was not dispersed. Also, the IA units have the right mix and competencies in specialist areas such as IT and treasury but with the least average of 2.407. Overall, an average of 1.956 indicates that most of the respondents were in agreement with the fact that the level of internal audit proficiency in the MMDAs in the Ashanti Region is sufficient and appropriate.

\subsection{Quality of Audit Work}

To effectively examine the quality of audit work by internal auditors in the MMDAs, the variables used in measuring quality of audit work were significantly tested. The test result is presented in Table 2 . All the variables used to assess quality of audit work were highly endorsed by the respondents. It is the view of the respondents that the internal audit units of the MMDAs in the Ashanti Region of Ghana adhere to the IA standards.

Table 2. Quality of audit work

\begin{tabular}{|c|c|}
\hline & $M(S D)$ \\
\hline IA unit adhere to the Institute of Internal Auditors (IIA) code of ethics & $1.296(.465)$ \\
\hline IAs are conducted in conformance with the international standard for professional practice of internal auditing & $1.370(.492)$ \\
\hline IA unit has a quality assurance and improvement programme & $1.888(1.154)$ \\
\hline IA unit organises or performs peer reviews or self -assessment of its performance & $2.185(.681)$ \\
\hline IA unit do regular follow-up to examine actions taken to correct problems identified & $2.074(1.106)$ \\
\hline IA plan is aligned to the key risks of the assembly and other quality assurance activities & $1.703(1.137)$ \\
\hline The evaluation of IA report by external auditors and other external authorities is positive & $2.148(1.166)$ \\
\hline IA reports are clear and accurate & $1.629(.741)$ \\
\hline The work of IA is timely and proactive in the conduct and reporting of issues to management & $2.037(.807)$ \\
\hline Management decision making process is strongly affected by reports, findings and recommendations of IA unit & $2.703(1.030)$ \\
\hline Overall Average & $2.028(0.986)$ \\
\hline
\end{tabular}

Source: Field data, 2014. 


\subsection{Organisational Independence}

The descriptive statistics of the elements of organisational independence of the IA work is depicted in Table 3 . Elements like 'internal audit unit has the authority to audit all parts of the assembly,' 'internal audit unit operates totally independently, can audit any issue it considers necessary of auditing,' and 'internal auditor participates in major decisions affecting the unit' had the most favourable response having recorded and average of 1.259, 1.629 and 1.667 respectively. The responses show a strong agreement by the respondents to the organisational independence of the IA units of the MMDAs. This follows the sequential theories of decentralisation which entail the devolution of decision-making authority over these policies, but this is not a necessary condition (Falleti, 2004).

Table 3. Organisational independence

\begin{tabular}{ll}
\hline & $M(S D)$ \\
\hline IA unit is an autonomous and independent body & $2.704(1.539)$ \\
IA unit has the authority to audit all parts of the MMDA & $1.259(.4465)$ \\
Detailed budget proposals are included in the annual work plan of the IA unit & $2.296(1.295)$ \\
IA performs other activities even if they are not defined as its direct responsibility & $2.074(.780)$ \\
IA operates totally independently, can audit any issue it considers necessary of auditing & $1.629(.687)$ \\
IA staff have free access to information and data about the MMDA & $2.963(6.060)$ \\
IA unit takes part in designing systems in the MMDA and in developing procedures for regulating their operations & $2.111(.891)$ \\
IA participates in major decisions affecting the IA unit & $1.667(.784)$ \\
Overall Average & $2.239(.272)$ \\
\hline
\end{tabular}

Source: Fieldwork, 2014.

\subsection{Career Advancement}

Career advancement opportunities refer to individuals' journey through learning, work and other aspects of professional life; one's progress in one's job, progress and development, promotion in rank or improvement in status. To describe internal audit effectiveness, the aforementioned are relevant to the variables of career advancement. From Table 4, variables relating to professional development training opportunities obtained the most favourable mean of 1.629 and standard deviation of 0.883 .

Table 4. Career advancement

\begin{tabular}{|c|c|}
\hline & $M(S D)$ \\
\hline Internal audit staff have the opportunity to participate in professional development training to enhance audit skills & $1.629(.883)$ \\
\hline Internal audit unit is highly regarded and respected within the MMDA & $2.593(1.337)$ \\
\hline Promotion for internal audit staff are not prolonged and interfered & $2.815(1.039)$ \\
\hline Overall average & $2.016(1.045)$ \\
\hline
\end{tabular}

Source: Field data, 2014.

The import of these responses is that because the internal audit staff are given the opportunity to embark on continuous development, they use their knowledge to bear thereby enhancing the effectiveness of their audit work. This aside, career advancement opportunities also serves as a motivational indicator to the staff to put in all their efforts when performing their functions since it will be rewarded by management. In light of this, Goodwin (2001) argued that the practice is designed to help the organisation to train internal auditor to perform a variety of activities across different departments within the organisation. The findings compare fervently with the institutional theory which according to Mihret et al. (2010) explains how organisational structures and practices are shaped through changes induced by normative pressures, including both external and internal sources such as laws and regulations, or by the professions. 


\subsection{Top Management Support}

Responses assessing top management support for the IA units of the MMDAs are presented in Table 5. The results show a negative response from respondents regarding the support of top management for IA function as most of them agreed to adverse questions on support from top management towards IA units. The respondents agreed to the fact that top management do not provide IA unit with the encouragement expected. This variable recorded an average as high as $(\mathrm{M}=2.888)$ and a standard deviation of 1.250. This shows that most of the IA units and the practice of IA techniques are not supported by the top management in the MMDAs.

Table 5. Top management support

\begin{tabular}{lc}
\hline & $M(S D)$ \\
\hline Top management does not provide IA unit with the encouragement expected & $2.888(1.250)$ \\
Management usually assign a small budget to the IA unit & $2.222(1.339)$ \\
Management does not provide assistance and encouragement for training and development for IA audit staff & $3.000(1.240)$ \\
IA units gets the attention of top management and focuses on issues audited by IA units & $2.185(.878)$ \\
$\begin{array}{l}\text { The number of employees in the IA unit is limited given the amount of auditing work planned and needed to be done in } \\
\text { the near future }\end{array}$ & $2.148(1.231)$ \\
Overall Average & $2.457(1.256)$ \\
\hline
\end{tabular}

Source: Field data, 2014.

\section{Regression Results and Testing of Hypotheses}

We now present the regression results based on the hypotheses formulated.

\section{$H_{1}$ : The professional proficiency of internal auditors affects IA effectiveness}

From Table 6, the result indicates a significant negative relationship between professional proficiency and internal audit effectiveness ( $\mathrm{t}-\mathrm{stat}=-2.828, \mathrm{p}=0.031<\mathrm{p}=0.05$ ). Hence, the hypothesis is not rejected because the professional proficiency of the internal auditors affects the IA effectiveness positively.

Table 6. Regression between independent variables and IA effectiveness

\begin{tabular}{|c|c|c|c|c|c|c|}
\hline \multirow[b]{2}{*}{ Model } & & \multicolumn{2}{|c|}{ Unstandardized Coefficients } & \multirow{2}{*}{$\begin{array}{l}\text { Standardized } \\
\text { Coefficients } \\
\text { Beta }\end{array}$} & \multirow[b]{2}{*}{$\mathrm{T}$} & \multirow[b]{2}{*}{ Sig. } \\
\hline & & $\mathrm{B}$ & Std. Error & & & \\
\hline (Constant) & & 3.500 & .513 & & 6.819 & .000 \\
\hline Internal audit proficiency & & -.512 & .280 & -.356 & -2.828 & .031 \\
\hline Quality of audit work & & .733 & .422 & .341 & 3.739 & .005 \\
\hline Organisational Independence & & -.889 & .098 & -.379 & -3.363 & .002 \\
\hline Career advancement & & .394 & .170 & .436 & 2.325 & .029 \\
\hline Top management support & & .269 & .188 & .286 & 1.432 & .166 \\
\hline $\mathrm{R}$ & R Square & Adjus & Square & & & \\
\hline $.766^{\mathrm{a}}$ & .587 & .345 & & & & \\
\hline
\end{tabular}

Dependent Variable: IA Effectiveness.

Source: Field data, 2014.

With a coefficient value of -0.356 indicating a negative relationship between professional proficiency of internal auditors and IA effectiveness, any increase in professional proficiency will necessarily not improve the effectiveness of the IA unit.

$\mathrm{H}_{2}$ : The quality of audit work of internal auditors affects IA effectiveness.

The hypothesis is not rejected on the premises that the alpha obtained is far below the benchmark alpha. The 
results from Table 6 show a significantly positive relationship between quality of audit work and IA effectiveness (t-stat $=3.739, \mathrm{p}=0.005<\mathrm{p}=0.05)$.

\section{$H_{3}$ : The organisational independence of internal auditors affects IA effectiveness.}

With the results showing a significantly negative relationship between organisational independence and IA effectiveness ( $\mathrm{t}$-stat $=-3.363, \mathrm{p}=0.02<\mathrm{p}=0.05$ ), the hypothesis is not rejected.

\section{$\mathrm{H}_{4}$ : Career opportunities for internal auditors affect IA effectiveness.}

The hypothesis is not rejected. The alpha obtained is far below the benchmark alpha. The results show a significantly positive relationship between career opportunities and IA effectiveness ( $\mathrm{t}$-stat $=2.325, \mathrm{p}=0.029<\mathrm{p}$ $=0.05$ ) with a coefficient of 0.436 .

\section{$H_{5}$ : Support from top management affects IA effectiveness.}

The hypothesis is rejected because support from top management do not affect IA effectiveness. The alpha obtained is higher than the bench mark alpha of 5 percent. The coefficient of 0.286 indicates an insignificant negative relationship between support from top management and IA effectiveness $(t-s t a t=1.432, p=0.166>p=$ $0.05)$.

\section{Conclusion}

Our main aim in this study is to examine IA effectiveness in decentralized local government administrative systems in Ghana's largest region. With the increased interest in the IA function in the district assemblies to enhance corporate governance, the public demand responsibility and precision from government in relation to the use of funds. Government can protect themselves by improving the IA procedures that will provide some level of assurance that local governments are not misapplying the nation's resources. A review of the function of the IA units revealed limitations on the scope of the audit function and unsatisfactory reporting relationship. With the establishment of a central IA Agency to enhance efficiency, accountability and transparency in the management of resources in the public sector, it is expected that IA units in the local districts in Ghana will enhance their effectiveness.

The results from our study indicate there exist effective IA units in Ghana's local districts. The factors identified as ensuring IA effectiveness are existence of audit committee, expertise and experience of internal auditors, management support, approved internal audit mandate and standards, unrestricted access to records, implementation of audit recommendations, adequate resources, organisational independence, regular training and quality of leadership of chief internal audit staff. We identified strong potential for independence of the IA departments and at the same time to independently evaluate management's effectiveness. Also, quality of audit work and career advancement have a positive impact on IA effectiveness with statistically significant coefficient but top management support was found to have no effect on IA effectiveness because of the statistically insignificant coefficient.

It is our assertion that there is professional proficiency in the IA units of the MMDAs in the Ashanti Region. The internal auditors possess the appropriate professional skills, qualifications and experience and participate in continuing professional development. To some extent, quality audit work is undertaken by the IA departments. The internal auditors adhere to auditing code of ethics, and comply with the international auditing standards. The quality of audit work has a significant positive effect on IA effectiveness. Moreover, to a large extent, we conclude that internal auditors in the local districts possess organizational independence. They have the authority to audit all segments of the district assemblies. They participate in major decisions affecting the unit and also take part in designing systems in the local districts. Internal auditors have career advancement opportunities. However, top management do not support internal auditors in the sense that, management do not provide internal audit unit with the encouragement expected and usually assign small budget to the units.

The IA units of the MMDAs need to be adequately and appropriately resourced by management. The availability of resources would enable the internal auditors to do quality and independent audit work. There should be regular in-service training and short term courses for internal auditors. This would help them to upgrade themselves in order to meet challenges of modern risk-based internal auditing. The promotion for internal audit staff should not be delayed or interfered with. The IA agency at the national level should monitor the I A units in the districts on regular basis to ensure that the units are achieving the desired results. Monitoring should include addressing IA findings and recommendations and ensuring that the management of the MMDAs take corrective actions. Contrary to the perception that audit quality in the public sector is usually compromised, the study revealed that there exists a significantly high quality of audit work due to compliance with the international auditing standards and local audit legislations. Professional proficiency, organisational independence, and career 
advancement were found to have statistically significant positive relationship with IA effectiveness, whiles top management support was found to have no effect on internal audit effectiveness.

Whiles acknowledging the limitation of this study with respect to the coverage of respondents, this study lays the foundation for further research to assess the implementation of the IA reports and recommendations over a long period. A comparative study of IA practices in public and private sector organisations could also be carried out to ascertain the significant differences that may exist in IA practices in the two sector.

\section{References}

Abbey, C. P. (2010). A study on the impact of the internal audit functions as a tool for instilling financial discipline in the public sector of Ghana. MBA dissertation. University of Wales Institute, Cardiff.

Abbott, A. (1988). The systems of professions: An essay on the division of expert Labor. Chicago: Chicago University Press.

Albrecht, W. S., Howe, K. R., Schueler, D. R., \& Stocks, K. D. (1988). Evaluating the Effectiveness of Internal Audit Departments. Institute of Internal Auditors, Altamonte Springs, FL.

Al-Twaijry, A., Brierley, J., \& Gwilliam, D. (2003). The development of internal audit in Saudi Arabia: An institutional theory perspective. Critical Perspectives on Accounting, 14(2), 507-531. http://dx.doi.org/10.1016/S1045-2354 (02)00158-2

Anderson, U. (1983). Quality Assurance for Internal Auditing. Institute of Internal Auditors, Altamonte Springs, FL.

Arena, M., \& Azzone, G. (2007). Internal Audit Departments: Adoption and Characteristics in Italian Companies. International Journal of Auditing, 11(2), 91-114. http://dx.doi.org/10.1111/j.1099-1123.2007.00357.x

Arena, M., \& Azzone, G. (2009). Identifying organisational drivers of internal audit effectiveness. International Journal of Auditing, 13(1), 43-60. http://dx.doi.org/10.1111/j.1099-1123.2008.00392.x

Asare, T. (2008). The role of Internal Auditing in the public sector of Ghana: Governance and Accountability. MSc Dissertation, Birmingham City University Business School, Birmingham, UK.

Asare, T. (2009). Internal Auditing in Public Sector: Promoting Good Governance and Performance Improvement. International Journal on Governmental Financial Management, 3(1), 15-27.

Baltaci, M., \& Yilmaz, S. (2006). Keeping an eye on Subnational Governments: Internal control and audit at local levels. World Bank Institute Washington, D. C.

Bota-Avram, C., \& Palfi, C. (2009). Measuring and assessment of internal audit's effectiveness. Economic Science Series, Annals of the University of Oradea, 18(3), 784-790.

Bou-Raad, G. (2000). Internal Auditors and value-added Approach: The New Business Regime. Managerial Auditing Journal, 15(2), 182-186. http://dx.doi.org/10.1108/02686900010322461

Bui, Y. N. (2009). How to write a master's thesis. London: Sage Publications International.

Cohen, A., \& Sayag, G. (2010). The effectiveness of internal auditing: An empirical examination of its determinants in Israeli organisations. Australian Accounting Review, 54(20), 296-307. http://dx.doi.org/10.1111/j.1835-2561.2010.00092.x

Coram, P. J., Ferguson, C., \& Moroney, R. A. (2007). Internal Audit, alternative internal audit structures \& the level of misappropriation of assets fraud. Accounting \& Finance, 48(4), 79-89. http://dx.doi.org/10.2139/ssrn.1021611

Cronbach, L. J. (1951). Coefficient alpha and the internal structure of tests. Psychometrika, 16(3), 297-334. http://dx.doi.org/10.1007/BF02310555

Dittenhofer, M. (2001). Internal auditing effectiveness: An expansion of present methods. Managerial Auditing Journal, 16(8), 23-45. http://dx.doi.org/10.1108/EUM0000000006064

Falleti, G. T. (2004). A sequential theory of decentralisation and its effects on: The intergovernmental balance of power: Latin American Cases in comparative perspective. Working Paper, Kellogg Institute.

Fernandez, S., \& Rainey, H. G. (2006). Managing successful organisational change in the public sector. Public Administration Review, 66(1), 168-176. http://dx.doi.org/10.1111/j.1540-6210.2006.00570.x

Flynn, B. B., Schroeder, R. G., \& Sakakibara, S. (1994). A framework for quality management research and an associated measurement instrument. Journal of Operations Management, 11(1), 339-366. 
http://dx.doi.org/10.1016/S0272-6963(97)90004-8

Ghartey, A. (2003). Challenges to establishing an effective organisational framework for effective internal auditing. Presentation at the World Bank Regional Workshop on Effective Use of Auditing Resources.

Glazer, A. S., \& Jaenike, H. R. (1980). A framework for evaluating and internal audit function. Foundations for Audit Ability Research and Education. Altamonte Springs.

Goodwin, J. (2001). Two factors affecting internal audit independence and objectivity: Evidence from Singapore. International Journal of Auditing, 5(2), 107-125. http://dx.doi.org/10.1111/j.1099-1123.2001.00329.x

Gouldner, A. W. (1958). Cosmopolitans and locals: Toward an analysis of Latent Social Identity. Administrative Science Quarterly, 3(1), 444-480. http://dx.doi.org/10.2307/2390795

Griffiths, D. (2006). Risk Based Internal Auditing. Three Views on Implementation. Retrieved from http://www.internalaudit.biz/files/implementation/Implementing

Institute of Internal Auditors (IIA). (2006). The Role of Auditing in Public Sector Governance. Altamonte Springs, FL.

Institute of Internal Auditors (IIA). (2008). International Professional Practices Framework-International Standards for the Professional Practice of Internal Audit. Altamonte Springs, FL, IIA Inc.

Institute of Internal Auditors (IIA). (1999). Definition of Internal Auditing. Altamonte Springs, FL: The Institute of Internal Auditors.

Institute of Internal Auditors (IIA) (2010). Measuring internal audit effectiveness and efficiency. IPPF-Practice guide. The Institute of Internal Auditors.

Jill, M. (1998). Is the control environment related to financial reporting decisions? Management Auditing, 13, 472-498. http://dx.doi.org/10.1108/02686909810236334

Karagiorgos, T., Drogalas, G., \& Giovanis, N. (2011). Evaluation of the effectiveness of internal audit in Greek Hotel Business. International Journal of Economic Sciences and Applied Research, 4(1), 19-34.

Karapetrovic, S., \& Willborn, W. (2000). Quality assurance and effectiveness of audit systems. International $\begin{array}{llll}\text { Journal of Quality \& Reliability } & \text { Management, } & \text { 17(6), }\end{array}$ http://dx.doi.org/10.1108/02656710010315256

Kent, R. A. (2007). Marketing research: Approaches, methods and applications in Europe. Thomson Learning.

Likert, R. A. (1932). A technique for the measurement of attitudes. Archives of Psychology, 1(2), 40-52.

Mihret, D. G., James, K., \& Mula, J. M. (2010). Antecedents and organisational performance implications of internal audit effectiveness: Some propositions and research agenda. Pacific Accounting Review, 22(3), 224-252. http://dx.doi.org/10.1108/01140581011091684

Mihret, D. G., \& Yismaw, A. W. (2007). Internal audit effectiveness: An Ethiopian public sector case study. Managerial Auditing Journal, 22(5), 470-484. http://dx.doi.org/10.1108/02686900710750757

Miles, M. B., \& Huberman, M. A. (1994). Qualitative Data Analysis: An Expanded Sourcebook (2nd ed.). Beverley Hills: Sage.

Mizrahi, S., \& Ness-Weisman, I. (2007). Evaluating the effectiveness of auditing in local municipalities using analytic hierarchy process: A general model and the Israeli example. International Journal of Auditing, 11, 187-210. http://dx.doi.org/10.1111/j.1099-1123.2007.00364.x

Nixon, A. (2005). Analysis: Corporate Governance-Internal audit, the new rock and roll. Journal of Accountancy, 135(1337), 48-49.

Nomo, P. (2009). Public sector performance management: The role of the internal auditing. Presentation at the 4th Annual Internal Audit Forum.

Pallant, J. (2005). SPSS survival manual: A step-by-step guide to data analysis using SPSS (2nd ed.). Sydney: Allen \& Unwin.

Pungas, K. (2003). Risk assessment as part of internal auditing in the government institutions of the Estonian Republic. EBS Review Summer, 42-46.

Reichel, M., \& Ramey, M. A. (1987). Conceptual frameworks for bibliographic education: Theory to Practice. Littleton Colorado: Libraries Unlimited Inc. 
Ridley, J., \& D'silva, K. (1997). A question of values. Internal Auditor, 2(1), 16-19.

Rittenberg, L. E. (1977). Audit Independence and System Design. Altamonte Springs. Institute of Internal Auditors.

Sarens, G., \& De Beelde, I. (2006). Internal Auditors perception about their role in risk management: A comparison between US and Belgian Companies. Managerial Auditing Journal, 21(1), 63-81. http://dx.doi.org/10.1108/02686900610634766

Sawyer, L. B. (1973). The Practice of Modern Internal Auditing. Altamonte Springs, Institute of Internal Auditors.

Schneider, A. (2003). An examination of whether incentive compensation and stock ownership affect internal auditor objectivity. Journal of Managerial Issues, 15(4), 486-497.

Smyth, R. (2002). Knowledge, interest and the management of educational change (Unpublished Doctoral Thesis), University of New England, Armidale.

Takeuchi, H. (1981). Productivity: Learning from the Japanese' California. Management Review, 12(2), 5-19. http://dx.doi.org/10.2307/41164926

White, A. W. (1976). The essentials for the effective internal audit department. Internal Auditor, 12(3), 30-33.

Winters, R. (2009). Achieving our potential. Internal Auditor, 65(3), 48-53.

Zikmund, W. (1997). Business Research Method. London: Cengage Learning.

\section{Copyrights}

Copyright for this article is retained by the author(s), with first publication rights granted to the journal.

This is an open-access article distributed under the terms and conditions of the Creative Commons Attribution license (http://creativecommons.org/licenses/by/4.0/). 